\title{
PENGARUH KONSUMSI LISTRIK DAN INDUSTRIALISASI TERHADAP PERTUMBUHAN EKONOMI
}

\author{
THE EFFECT OF ELECTRICITY CONSUMPTION AND INDUSTRIALIZATION \\ ON ECONOMIC GROWTH
}

\author{
Pihri Buhaerah \\ Research Associate/Economist The Indonesian Institute (TII) \\ email : pihri.buhaerah@gmail.com
}

\begin{abstract}
Abstrak
Hingga saat ini struktur PDB masih didominasi konsumsi rumah tangga. Akibatnya, tingkat pertumbuhan ekonomi bergeming di angka 5 persen. Untuk mendongkrak kinerja pertumbuhan ekonomi, industrialisasi mutlak dikedepankan. Pada prosesnya, ketersediaan energi terutama energi listrik tentu saja menjadi salah satu komponen utamanya. Atas dasar itu, maka tujuan utama penelitian ini adalah untuk mengukur pengaruh listrik dan industrialisasi terhadap pertumbuhan ekonomi. Untuk mencapai tujuan penelitian tersebut, penelitian ini menggunakan model ARDL dan data sekunder dengan periode sampel mulai dari 1987 hingga 2016. Hasil analisis menunjukkan bahwa variabel porsi barang manufaktur yang diekspor dan indeks harga komoditas non-energi secara empiris terbukti signifikan baik dalam jangka pendek maupun jangka panjang. Sementara itu, nilai koefisien konsumsi listrik dan angka partisipasi sekolah tinggi memiliki dampak yang berbeda di jangka panjang dan jangka pendek. Konsumsi listrik memiliki dampak yang lebih tinggi dan signifikan dalam jangka pendek. Sayangnya, dalam jangka panjang, efek konsumsi listrik terhadap pertumbuhan ekonomi tidak signifikan.Sementara itu, variabel angka partisipasi sekolah tinggi hanya berdampak signifikan dalam jangka panjang. Menariknya, semua variabel independen yang dilibatkan kecuali variabel konsumsi listrik memiliki nilai koefisien yang lebih tinggi dalam jangka panjang yang mengindikasikan bahwa keempat variabel tersebut memiliki daya dorong yang lebih kuat terhadap pertumbuhan ekonomi dalam jangka panjang daripada dalam jangka pendek. Selain itu, hasil uji kointegrasi bounds menunjukkan bahwa kelima variabel penjelas yang dilibatkan dalam penelitian ini memiliki hubungan jangka panjang dengan pertumbuhan ekonomi.

Kata kunci:konsumsi listrik, industrialisasi, pertumbuhan ekonomi, autoregressive distributed lag model
\end{abstract}

Klasifikasi JEL: C22, O14, Q43

\begin{abstract}
The structure of GDP nowadays is still dominated by household consumption. As a result, economic growth stands at 5 percent. To boost economic growth performance, industrialization should be taken into account. In the process, energy availability particularly electricity becomes one of the main components. For this reason, the main purpose of this study is to measure the effect of electricity and industrialization on economic growth. To do so, this study employs ARDL model and uses secondary data with sample period from 1987 to 2016. Regression result analysis shows that manufactures exports and non-energy commodity price indexare empirically significant both in the short-run and long-run. Meanwhile, electricity consumption and tertiary school enrollment has a different effect both in the short-run and the long-run. Electricity consumption plays more important role on increasing real GDP than other variables in the short-run. However, the coefficient value of electricity consumption is not significant in the long-run. In contrast, tertiary school enrollment is only significant in the long-run.Interestingly, all independent variables except electricity consumption havehigher coefficients in the long-run indicating that those variables have higher impact in the long-run rather than in the short-run. In addition, bounds cointegration test shows that all explanatory variables involved in this study have a long-term relationship with economic growth.

Keywords: electricity consumption, industrialization, economic growth, autoregressive distributed lag model

JEL Classification: C22, O14, Q43
\end{abstract}




\section{PENDAHULUAN}

Tujuan pembangunan ekonomi suatu negara berpenghasilan rendah sejatinya untuk menuju negara berpenghasilan tinggi. Sayangnya, upaya menuju negara berpenghasilan tinggi tak mudah dilakukan. Bahkan, seringkali pada prosesnya terjebak dalam kondisi yang dinamakan middle income trap(MIT) atau jebakan pendapatan menengah. Istilah tersebut merujuk pada situasi di mana suatu negara berpenghasilan menengah sudah tidak mampu lagi berkompetisi di tingkat global dengan hanya mengandalkan komoditas padat karya disebabkan tingkat upah yang sudah relatif tinggi (Paus, 2017). Pada saat yang sama, negara tersebut juga tidak dapat bersaing dalam kegiatan ekonomi yang bernilai tambah tinggi dalam skala ekonomi yang cukup luas karena tingkat produktifitasnya secara relatif masih tergolong rendah (Paus, 2017). Akibatnya, pertumbuhan ekonomi cenderung melambat dan kurang potensialuntuk mengangkat standar hidup masyarakat. Akibatnya, pertumbuhan ekonomi cenderung melambat, upah yang stagnan atau turun, dan bertumbuhnya ekonomi informal (Paus, 2017). Dengan demikian, jebakan pendapatan menengah dapat diasosiasikan sebagai gagalnya pembangunan suatu negara berpenghasilan menengahuntuk naik ke level yang lebih tinggi, yakni negara berpenghasilan tinggi.

Sejumlah penelitian mencoba mengangkat isu ini guna mendapatkan gambaran yang utuh terkait faktor penyebab utama suatu negara terjebak dalam pendapatan menengah. Misalnya saja, Felipe (2012a) menemukan bahwa dari 52 negara berpenghasilan menengah pada 2010, 35 negara telah masuk ke dalam jebakan pendapatan menengah dengan rincian 30 masuk ke dalam jebakan pendapatan menengah bawah dan 5 masuk ke dalam jebakan pendapatan menengah atas. Sisanya, 8 dari 17 negara yang tidak masuk dalam kategori jebakan pendapatan menengah berisiko masuk ke dalam jebakan pendapatan menegah bawah (3 negara) dan menengah atas (5 negara). Felipe (2012b) selanjutnya menemukan bahwa negara-negara yang berhasil tidak masuk ke dalam jebakan pendapatan menengah adalah mereka yang memiliki kemampuan untuk menghasilkan produk-produk yang lebih bervariasi dan terkoneksi dengan baik (mesin, logam, dan kimia) serta menggunakan teknologi produksi yang lebih canggih. Paus (2017) juga menemukan hal yang sama dengan menyatakan bahwa faktor utama negara-negara terperangkap ke dalam jebakan pendapatan menengah adalah karena rendahnya kemampuan inovasi domestik.

Sayangnya, penelitian-penelitian yang terkait jebakan pendapatan menengah belum memasukkan konsumsi listrik sebagai salah satu variabel penting dalam proses transformasi struktural. Atas dasar itu, sejumlah penelitian mencoba mengukur keterkaitan antara konsumsi listrik dan pertumbuhan ekonomi. Misalnya saja, Yoo (2005) menginvestigasi hubungan antara konsumsi listrik dan pertumbuhan ekonomi di Korea Selatan untuk periode 1970-2002. Hasilnya, Yoo (2005) menemukan konsumsi listrik memiliki hubungan kausalitas (dua arah) dengan pertumbuhan ekonomi. Ini mengindikasikan bahwa tingkat konsumsi listrik yang tinggi akan mendorong pertumbuhan ekonomi dan sebaliknya pertumbuhan ekonomi yang tinggi dibutuhkan untuk meningkatkan tingkat konsumsi listrik. Hal senada namun sedikit berbeda juga ditemukan Yoo dan Lee (2010). Menurut mereka, hubungan antara konsumsi listrik dengan pertumbuhan ekonomi secara statistik signifikan dan berbentuk seperti kurva U-terbalik. Artinya, semakin tinggi skala ekonomi, maka konsumsi listrik pun akan meningkat. Namun, semakin maju ekonomi suatu negara, maka sektor industri yang dominan akan bergeser dari industri berat ke industri manufaktur ringan dan jasa yang berdampak pada turunnya konsumsi listrik.

Sementara itu, dengan menggunakan data periode 1980-2003 dari negara-negara anggota OPEC, hasil penelitian Squally (2007) menunjukkan bahwa tingkat konsumsi listrik dan pertumbuhan ekonomi memiliki hubungan jangka panjang. Meski demikian, derajat hubungan tersebut berbeda-beda di tiap negara dengan rincian sebagai berikut. Konsumsi listrik terbukti berdampak signifikan terhadap pertumbuhan ekonomi di Indonesia, Iran, Nigeria, Qatar, dan Venezuela, kurang berdampak di Aljazair, Irak, dan Libya, tidak 
berdampak sama sekali di Kuwait, Arab Saudi, Uni Emirat Arab (UEA). Sebaliknya, hasil penelitian Acaravci dan Ozturk (2010) menyimpulkan bahwa konsumsi listrik tidak memiliki hubungan jangka panjang dengan PDB riil dengan menggunakan data dari 15 negara-negara transisi (Albania, Belarusia, Bulgaria, Ceko, Estonia, Latvia, Lithuania, Macedonia, Moldova, Polandia, Rumania, Rusia, Serbia, Slovakia, dan Ukraina) untuk periode 1990-2006.

Sayangnya, penelitian-penelitian di atas baru melihat hubungan kausalitas dan jangka panjang antara konsumsi listrik dan pertumbuhan ekonomi. Dengan kata lain, penelitian-penelitian tersebut hanya melibatkan dua variabel yakni konsumsi listrik dan pertumbuhan ekonomi. Guna mendapatkan perspektif yang lebih luas, perlu melibatkan lebih banyak variabel terutama indikator industrialisasi dengan merujuk pada negara-negara yang sukses menjalankan transfromasi struktural. Pengalaman di beberapa negara industri maju seperti Korea Selatan juga menunjukkan bahwa level industrialisasi sangat menentukan tingkat konsumsi listrik suatu negara. Dengan kata lain, makin tinggi tingkat konsumsi listrik suatu negara, maka level pembangunan ekonomi negara tersebut umumnya juga semakin tinggi. Atas dasar itu, maka pengaruh listrik dan industrialisasi terhadap pertumbuhan ekonomi di Indonesia menjadi penting untuk dikaji.

\section{TINJAUAN PUSTAKA}

Salah satu contoh negara yang sukses mentransformasi perekonomiannya adalah Korea Selatan. Korea Selatan berstatus sebagai negara berpenghasilan menengah bawah pada 1969, kemudian naik kasta menjadi negara berpenghasilan menengah atas pada 1988, dan akhirnya menjadi negara berpenghasilan tinggi pada 1995. Menariknya, pada proses menuju negara berpenghasilan menengah atas, industrialisasi di Korea Selatan dibarengi dengan kontribusi sektor manufaktur rata-rata sebesar 24 persen terhadap PDB, konsumsi listrik rata-rata sebesar $923 \mathrm{kWh}$ per kapita, proporsi pekerja di sektor industri rata-rata sebesar 26 persen, dan kontribusi konsumsi sektor rumah tangga terhadap PDB rata-rata sebesar 48 persen.

Berkaca dari pengalaman Korea Selatan tersebut, maka penelitian ini mencoba mengungkap pengaruh konsumsi listrik bersama dengan industrialisasi terhadap pertumbuhan ekonomi di Indonesia. Adapun sejumlah alasan yang mendasari penelitian ini diuraikan sebagai berikut. Pertama, nilai PDB per kapita Indonesia berhasil menembus level psikologis yakni \$ 10.000 (PPP in 2011 \$) pada 2004. Jika tidak ingin terjebak dalam jebakan pendapatan menengah pada 2030 mendatang, maka nilai PDB per kapita Indonesia harus lebih besar dari \$ 16.000 (PPP in 2011 \$). Artinya, jika benar-benar ingin naik ke level kelompok negara berpenghasilan tinggi, Indonesia harus serius mentransformasi perekonomiannya dan hanya satu cara untuk menuju ke sana yaitu dengan memperkuat kontribusi sektor manufakturnya terhadap PDB melalui industrialisasi. Masalahnya, perekonomian Indonesia dewasa ini tidak ditopang oleh kinerja sektor industrinya. Bahkan, bisa dikatakan peranan sektor industri Indonesia sudah mencapai titik nadir. Hal ini terindikasi dari kontribusi sektor manufaktur terhadap PDB yang kian menurun dari 30 persen terhadap PDB pada 2008 menjadi hanya 20 persen dari PDB pada saat ini. Karena itu, tidaklah mengherankan jika laju industri manufaktur tidak pernah beranjak dari angka 4 persen.

Untuk mewujudkannya, pembangunan sektor manufaktur harus dibangkitkan kembali menjadi mesin utama pertumbuhan ekonomi nasional. Rodrik (2017) mengemukakan beberapa alasan yang mendukung tesis tersebut. Pertama, mengambil teknologi dari luar negeri cenderung lebih mudah dan menciptakan pekerjaan dengan produktifitas tinggi. Kedua, pekerjaan di sektor manufaktur tidak memerlukan keterampilan yang tinggi sehingga dapat menyerap tenaga kerja yang lebih banyak. Ketiga, permintaan terhadap produk manufaktur tidak dibatasi oleh pendapatan dalam negeri yang rendah karena hasil produksi di sektor ini dapat diekspor. Rodrik (2017) juga menambahkan agar perubahan struktural ke sektor manufaktur berjalan dengan baik, perlu diiringi dengan migrasi pekerja di sektor pertanian yang lebih 
Tabel 1. Level Konsumsi Listrik di ASEAN

\begin{tabular}{cccc}
\hline No. & Negara & $\begin{array}{c}\text { Konsumsi Listrik } \\
(\text { kWh per kapita) }\end{array}$ & $\begin{array}{c}\text { Konsumsi Listrik } \\
\text { (kWh per kapita) }\end{array}$ \\
\hline 1 & Singapura & 8610 & 2014 \\
2 & Malaysia & 4160 & 8845 \\
3 & Thailand & 2307 & 4596 \\
4 & Vietnam & 1017 & 2540 \\
5 & Indonesia & 634 & 1439 \\
\hline
\end{tabular}

Sumber: World Development Indicators (2017)

tinggi ke sektor manufaktur dibandingkan ke sektor jasa.

Pengalaman dari Korea Selatan juga menunjukkan bahwa untuk mencapai level negara industri maju, kontribusi sektor manufaktur terhadap PDB idealnya berada di atas 30\%. Untuk mencapai level tersebut, dibutuhkan kapasitas listrik terpasang minimal 500 watt per kapita. Sayangnya, data PLN (2017) menginformasikan bahwa kapasitas terpasang Indonesia saat ini baru mencapai 55.000 MW atau setara dengan 212 watt per kapita. Adapun Singapura, Malaysia, dan Thailand, kapasitas listrik terpasang sudah di atas 500 watt per kapita. Hal itu mengindikasikan bahwa kapasitas pasokan listrik saat ini tidak memungkinkan sektor industri untuk tumbuh lebih tinggi. Dengan demikian, posisi dan akselerasi peningkatan kinerja kelistrikan di Indonesia relatif tertinggal dibandingkan dengan beberapa negara Asia lainnya (Adam, 2016). Tak heran jika hasil studi Sambodo dan Oyama (2011) tidak menemukan hubungan jangka pendek dan jangka panjang antara konsumsi listrik dengan pertumbuhan ekonomi.

Sementara itu, konsumsi listrik nasional hanya sebesar $812 \mathrm{kWh}$ per kapita. Jika dibandingkan dengan negara ASEAN lainnya, angka tersebut jelas mengindikasikan kita jauh tertinggal (lihat tabel 1). Menurut data Bank Dunia (2017), konsumsi listrik di Singapura, Malaysia, Thailand, dan Vietnam masing-masing sebesar 8845, 4596, 2540, dan $1439 \mathrm{kWh}$ per kapita.

Dengan demikian, ketersediaan pasokan energi terutama listrik yang memadai dan terjangkau menjadi krusial dalam pembangunan sektor industri karena salah satu aspek kritis dalam dalam bisnis sektor industri pengolahan adalah jaminan ketersediaan energi listrik (Bank Indonesia, 2015). Implikasinya, investasi ketenagalistrikan perlu digenjot karena diantara 10 negara anggota ASEAN, Indonesia adalah negara yang sangat membutuhkan suntikan investasi (Yoo \& Kim, 2006). Semua itu mengkonfirmasi bahwa listrik dan industrialisasi adalah komponen utama dan tidak terpisahkan dalam proses menuju negara berpenghasilan tinggi sebagaimana yang terjadi di Korea Selatan.

\section{METODOLOGI PENELITIAN}

\section{Operasionalisasi Variabel dan Sumber Data}

Variabel dependen dalam penelitian ini adalah pertumbuhan ekonomi. Pertumbuhan ekonomi dalam penelitian diturunkan dari variabel PDB riilseperti yang digunakan oleh Yoo (2005) dan Yoo dan Kim (2006) pada saat mengukur pengaruh konsumsi listrik terhadap pertumbuhan ekonomi di Korea Selatan dan Indonesia.Sementara itu, untuk variabel independen terdiri atas nilai konsumsi daya listrik, indikator industrialisasi, angka partisipasi sekolah tinggi, dan indeks harga komoditas non-energi. Variabel konsumsi listrik didefinisikan sebagai nilai konsumsi daya listrik dalam kWh per kapita. Sementara indikator industrialisasi diwakili oleh dua variabel yaitu porsi barang manufaktur yang diekspor terhadap total barang ekspor dan variabel persentase tenaga kerja di sektor industri terhadap total tenaga kerja.Kedua variabel tersebut dipilih karena proses industrialisasi yang dewasa ditandai dengan peningkatan kontribusi sektor manufaktur dalam struktur PDB yang dibarengi dengan peningkatan pekerja di sektor industri yang lebih tinggi dibandingkan sektor pertanian. Jika tidak, proses industrialisasitersebut tidak akan 
Tabel 1. Variabel dan Sumber Data

\begin{tabular}{llccc}
\hline \multicolumn{1}{c}{ Variabel } & \multicolumn{1}{c}{ Keterangan } & Satuan & Periode Sampel & Sumber \\
\hline LRGDP & PDB rill & Logaritma & $1987-2016$ & WDI \\
LELCON & Konsumsi daya listrik & Logaritma & $1987-2016$ & WDI \\
MANE & Porsi barang manufaktur yang diekspor & $\%$ & $1987-2016$ & WDI dan BPS \\
EMI & Persentase pekerja di sektor industri & $\%$ & $1987-2016$ & WDI dan BPS \\
SET & Angka partisipasi sekolah tinggi & $\%$ & $1987-2016$ & WDI \\
LINE & Indeks harga komoditas non-energi & Logaritma & $1987-2016$ & WBCPD \\
\hline
\end{tabular}

Tabel 2.Ringkasan Statistik

\begin{tabular}{lccccc}
\hline \multicolumn{1}{c}{ Variabel } & Obs & Mean & Std.Dev & Min & Max \\
\hline LRGDP & 30 & 16,91 & 0,28 & 16,42 & 17.40 \\
LELCON & 30 & 5,93 & 0,62 & 4,65 & 6,86 \\
MANE & 30 & 44,10 & 8,34 & 25,02 & 57,12 \\
EMI & 30 & 17,43 & 3,36 & 8,26 & 22,24 \\
SET & 30 & 16,38 & 7,01 & 6,86 & 29,56 \\
LINE & 30 & 4,16 & 0,32 & 3,75 & 4,79 \\
\hline
\end{tabular}

matang dan selanjutnya akan bertransformasi menjadi proses deindustrialisasi dini.

Selain itu, penelitian ini juga melibatkan variabel-variabel lain seperti angka partisipasi sekolah tinggi dan indeks harga komoditas non-energi. Variabel angka partisipasi sekolah tinggi dilibatkan dalam kajian ini karena kenyataan empiris yang ada menunjukkan, modal manusia menjadi kunci untuk mentransformasi industri yang berbasis padat karya ke industri yang berbasis tekonologi dan inovasi (Buhaerah, 2018). Variabel indeks harga komoditas non-energijuga perlu dilibatkan dalam penelitian ini karena variabel ini masih menjadi variabel determinan dalam struktur PDB Indonesia hingga saat ini. Data kelima variabel tersebut merupakan data sekunder yang diambil dari World Development Indicators (WDI) - Bank Dunia, Badan Pusat Statistik (BPS), dan World Bank Commodity Price Data (WBCPD). Satuan, periode, dan sumber data per variabel ditampilkan pada tabel di bawah ini.

Selanjutnya, sebelum menjalankan estimasi, gambaran secara deskriptif dari masing-masing variabel juga perlu ditampilkan. Variabel PDB riil, konsumsi daya listrik, dan indeks harga komoditas non-energi dalam bentuk logaritmauntuk memudahkan interpretasi secara ekonomi. Sementara itu, variabel lainnya seperti porsi barang manufaktur yang diekspor, pekerja di sektor industri, angka partisipasi sekolah tinggi, tidak dalam bentuk logaritma karena satuannya sudah dalam bentuk persentase. Adapun ringkasan statistik untuk variabel yang disertakan dalam penelitian ini adalah sebagai berikut.

\section{Metode}

Untuk melihat pengaruh konsumsi listrik dan industrialisasi terhadap pertumbuhan ekonomi, studi ini menggunakan model Autoregressive Distributed Lag (ARDL). Model ARDL yang digunakan dalam penelitian ini mengadopsi model ARDL yang dikembangkan Shin (1998) dan Pesaran et al. (2001).Penelitian ini menggunakan model ARDL dengan beberapa alasan. Pertama, model ARDL menyediakan informasi atau persamaan efek jangka panjang dan jangka pendek secara bersamaan. Keempat, persamaan yang digunakan untuk mengestimasi hubungan kointegrasi antar variabel merupakan persamaan tunggal. Ketiga, model ARDL lebih fleksibel dibandingkan model kointegrasi lainnya seperti pendekatan Johansen (1991) karena tidak mengharuskan adanya uji stasioner per variabel. Keempat, model ARDL dapat digunakan meski periode sampel yang digunakan tidak terlalu panjang. Kelima, berbeda dengan uji kointegrasi standar, tiap variabel dalam model ARDL memungkinkan memiliki lag yang berbeda-beda.

Adapun model ARDL yang digunakan untuk mengestimasi koefisien jangka panjang dan jangka pendek sebagai berikut. 
Tabel 3.Hasil Uji Akar Unit

\begin{tabular}{|l|r|c|r|c|c|c|c|c|}
\hline \multirow{2}{*}{ Variabel } & \multicolumn{4}{|c|}{ Level } & \multicolumn{4}{c|}{ First Difference } \\
\cline { 2 - 9 } & ADF & Hasil & \multicolumn{1}{|c|}{ PP } & Hasil & ADF & Hasil & PP & Hasil \\
\hline LRGDP & 0,808 & NS & 0,545 & NS & $-5,195$ & S & $-5,182$ & S \\
\hline LELCON & $-2,527$ & NS & $-2,563$ & NS & $-5,035$ & S & $-4,983$ & S \\
\hline MANE & $-2,456$ & NS & $-2,483$ & NS & $-3,432$ & S & $-3,405$ & S \\
\hline EMI & $-1,681$ & NS & $-1,568$ & NS & $-8,054$ & S & $-8,658$ & S \\
\hline SET & $-0,243$ & NS & 0,107 & NS & $-6,119$ & S & $-6,226$ & S \\
\hline LINE & $-1,418$ & NS & $-1,442$ & NS & $-5,916$ & S & $-5,815$ & S \\
\hline
\end{tabular}

Tabel 4. Hasil Seleksi Lag

\begin{tabular}{lcc}
\hline \multicolumn{1}{c}{ Variabel } & \multicolumn{2}{c}{$\begin{array}{c}\text { Schwarz-Bayesian Information Criterion (SBIC) } \\
\text { Variabel }\end{array}$} \\
\hline PDB riil & LRGDP \\
Konsumsi listrik per kapita & LELCON & 2 \\
Porsi barang manufaktur yang diekspor & MANE & 1 \\
Porsi pekerja di sektor industri & EMI & 0 \\
Angka partisipasi sekolah tinggi & SET & 0 \\
Indeks harga komoditas non-energi & LINE & 2 \\
\hline
\end{tabular}

$\Delta$ LRGDP $_{\mathrm{t}}=\alpha_{0}+\alpha_{1} \mathrm{LELCON}_{\mathrm{t}-1}+\alpha_{2}$ MANE $_{\mathrm{t}-1}+\alpha_{3} \mathrm{EMI}_{\mathrm{t}-1}$ $+\sum_{\mathrm{i}=1}^{\mathrm{n}} \alpha_{4} \Delta$ LELCON $_{\mathrm{t}-\mathrm{i}}+\sum_{\mathrm{i}=1}^{\mathrm{n}} \alpha_{5} \Delta$ MANE $_{\mathrm{t}-\mathrm{i}}+\sum_{\mathrm{i}=1}^{\mathrm{n}} \alpha_{6} \Delta \mathrm{EMI}_{\mathrm{t}-\mathrm{i}}+\varepsilon_{\mathrm{t}}$

dimana $\mathrm{n}$ dan berturut-turut adalah jumlah lag optimal dan first difference dari variabel yang dilibatkan dalam pembangunan model regresi. Bagian pertama dari persamaan diatas yakni $\alpha_{1}, \alpha_{2}$, dan $\alpha_{3}$ merupakan koefisien untuk jangka panjang. Sedangkan bagian kedua yang terdiri atas $\alpha_{4}, \alpha_{5}, \alpha_{6}$, dan $\alpha_{7}$ merupakan koefisien untuk jangka pendek. Hipotesis nol(null hypothesis) untuk persamaan di atas adalah tidak ada kointegrasi jika $\mathrm{H}_{0}: \alpha_{1}=\alpha_{2}=\alpha_{3}=0$ sementara hipotesis alternatifnya adalah terdapat kointegrasi jika $\mathrm{H}_{1}: \alpha_{1} \neq \alpha_{2} \neq \alpha_{3} \neq 0$. Jika statistik uji-F (F-test statistic) lebih tinggi daripada batas atas nilai kritis (upper bound critical values), maka dapat disimpulkan bahwa terdapat hubungan jangka panjang antar variabel. Sebaliknya, jika statistik uji-F lebih kecil daripada batas atas nilai kritis, maka kita tidak dapat menolak hipotesis nol (tidak ada kointegrasi).

\section{HASIL DAN PEMBAHASAN}

\section{Uji Stasioneritas}

Meski model ARDL tidak mengharuskan adanya uji akar unit, namun uji akar unit tetap dibutuhkan untuk memastikan bahwa tak ada satu pun variabel yang I(2). Alasannya, nilai F-statistik hitung menjadi tidak valid manakala ada variabel yang terintegrasi pada order 2 atau lebih (Odhiambo, 2010).Untuk melihat ada tidaknya akar unit, studi ini menggunakan uji Augmented Dickey Fuller (ADF), dan Phillips-Perron (PP). Hasil uji akar unit dengan menggunakan kedua uji tersebut menunjukkan bahwa semua variabel tidak stasioner (NS) pada leveldan stasioner (S) pada first difference-nya (lihat tabel 1).

\section{Seleksi Lag}

Jika dibandingkan dengan pendekatan kointegrasi lainnya, salah satu fitur unggulan dalam model ARDLterletak pada jumlah lag yang dilibatkan dan memungkinkan berbeda-beda untuk setiap variabel. Adapun kriteria seleksi lag pada model ARDL dapat menggunakan kriteria Akaike Information Criterion maupun Schwarz-Bayesian Information Criterion (SBIC). Namun, kriteria pemilihan lag dalam studi ini hanya menggunakan salah satunya saja, yakni kriteria SBIC. Hasil simulasi Pesaran and Shin (1998) menyimpulkan bahwa SBIC sedikit lebih baik daripada AIC karena SBIC terbukti lebih konsisten daripada AIC dalam pemilihan model. Adapun lag yang terpilih adalah lag dengan nilai SBIC yang paling rendah. Hasil pemilihan jumlah lag yang dilibatkan dengan menggunakan SBIC selengkapnya disajikan pada tabel 4 . 
Tabel 5. Hasil Estimasi Koefisien Jangka Panjang

\begin{tabular}{lcccl}
\hline & \multicolumn{3}{c}{ Variabel Dependen: LRGDP } & \\
Variabel Penjelas & Lag & Koefisien & p-value & Hasil \\
LELCON & 1 & $\begin{array}{c}0.113 \\
(0.0930)\end{array}$ & 0.242 & Tidak signifikan \\
MANE & 0 & $\begin{array}{c}0.008 \\
(0.0038)\end{array}$ & 0.048 & Signifikan \\
EMI & 0 & $\begin{array}{c}0.007 \\
(0.0114)\end{array}$ & 0.553 & Tidak signifikan \\
LINE & 0 & $\begin{array}{c}0.328 \\
(0.1073)\end{array}$ & 0.007 & Signifikan \\
SET & 0.018 & 0.014 & Signifikan \\
\hline
\end{tabular}

\section{Efek Jangka Panjang}

Variabel kunci yang dilibatkan dalam studi ini adalah konsumsi listrik (LELCON) dan indikator industrialisasi yang diwakili oleh variabel porsi barang manufaktur yang diekspor (MANE) dan porsi tenaga kerja di sektor industri (EMI). Hasil estimasi menunjukkan bahwa semua nilai koefisien variabel kunci adalah positif. Artinya, dalam jangka panjang, semua variabel memiliki pengaruh yang positif terhadap pertumbuhan ekonomi. Namun, tidak semua variabel yang dilibatkan memberikan pengaruh yang signifikandalam jangka panjang seperti variabel LELCON dan EMI. Meski tidak signifikan, namun variabel LELCON dan EMI memiliki potensi yang tinggi guna meningkatkan nilai PDB riil.

Menariknya, dalam jangka pajang, dua variabel yang memiliki nilai koefisien tertinggi adalah variabel indeks harga komoditas non-energi (LINE) dan variabel LELCON. Sayangnya, koefisien variabel LELCON belum memberikan pengaruh yang cukup signifikan terhadap pertumbuhan ekonomi dalam jangka panjang. Adapun variabel LINE dengan nilai koefisien sebesar 0,33 mengindikasikan bahwa kenaikan 1 persen indeks harga komoditas non-energi akan menaikkan nilai PDB riil sebesar 3,3 persen. Variabel kunci lainnya, MANE, dengan nilai koefisien sebesar 0,05 mengindikasikan bahwa kenaikan 1 persen porsi barang manufaktur yang diekspor akan menaikkan nilai PDB riil sebesar 0,5 persen. Jika dibandingkan dengan nilai koefisien LINE, nilai koefisien MANE jauh lebih rendah.
Artinya, variabel LINEjauh lebih kuat dalam mendongkrakPDB riildibandingkan variabel MANE. Atau, dalam konteks industrialisasi, pertumbuhan ekonomi masih sangat bergantung dari harga komoditas primer.

Selain ketiga variabel di atas, studi ini juga melibatkan variabel angka partisipasi sekolah tersier/tinggi (SET). Variabel ini terbukti secara statistik positif dan signifikan mempengaruhi PDB riil. Sayangnya, nilai koefisien variabel ini lebih rendah daripada variabel LINE dan LELCON.Dengan nilai koefisien sebesar 0,02 mengindikasikan bahwa kenaikan 1 persen angka partisipasi sekolah tinggi berpotensi menaikkan nilai PDB riil sebesar 0,2 persen. Angka itu juga mengindikasikan bahwa jika ingin mendongkrak pertumbuhan ekonomi yang lebih tinggi, proses industrialisasi perlu diiringi dengan perbaikan dalam kualitas sumber daya manusia di level pendidikan tinggi.

\section{Efek Jangka Pendek}

Dalam jangka pendek, pengaruh konsumsi listrik dan harga komoditas non-energi tetap masih yang paling tinggi. Menariknya, dalam jangka pendek, nilai koefisien variabel LELCON selain signifikan namun juga lebih tinggi daripada variabel LINE. Dengan nilai koefisien 0,55, mengindikasikan bahwa kenaikan 1 persen konsumsi listrik akan meningkatkan PDB riil sebesar 5,5 persen dalam jangka pendek. Adapun variabel LINE, dengan nilai koefisien sebesar 0,15 , mengindikasikan bahwa kenaikan 1 persen indeks harga komoditas non-energi akan 
Tabel 6. Hasil Estimasi Koefisien Jangka Pendek

\begin{tabular}{|c|c|c|c|c|}
\hline \multicolumn{5}{|c|}{ Variabel Dependen: LRGDP } \\
\hline Variabel Penjelas & Differences & Koefisien & p-value & Hasil \\
\hline LELCON & $1^{\text {st }}$ & $\begin{array}{c}0.551 \\
(0.1934)\end{array}$ & 0.011 & Signifikan \\
\hline MANE & $1^{\text {st }}$ & $\begin{array}{c}0.004 \\
(0.0014)\end{array}$ & 0.021 & Signifikan \\
\hline EMI & $1^{\text {st }}$ & $\begin{array}{c}0.003 \\
(0.0053)\end{array}$ & 0.570 & Tidak signifikan \\
\hline LINE & $1^{\text {st }}$ & $\begin{array}{c}0.147 \\
(0.0419)\end{array}$ & 0.003 & Signifikan \\
\hline SET & $1^{\text {st }}$ & $\begin{array}{c}0.005 \\
(0.0033)\end{array}$ & 0.138 & Tidak signifikan \\
\hline
\end{tabular}

meningkatkan PDB riil sebesar 1,5 persen dalam jangka pendek.

Sementara itu, pengaruh porsi barang manufaktur yang diekspor terhadap PDB riil juga tetap signifikan.Sayangnya, dalam jangka pendek, pengaruh sektor ini terhadap PDB riil hampir sama rendahnya dengan variabel EMI yang tercermin dari nilai koefisiennya. Dengan nilai koefisien sebesar 0,004, mengindikasikan bahwa kenaikan 1 persen porsi barang manufaktur yang diekspor, akan meningkatkan PDB riil sebesar 0,04 persen. Sayangnya, daya dorong variabel ini masih kalah dibandingkan variabel konsumsi listrik dalam mendongkrak PDB riil. Alasannya, nilai koefisien variabel LELCONlebih tinggi dibandingkan variabel MANE. Terakhir, untuk variabel SET dengan nilai koefisien sebesar 0,005 , mengindikasikan bahwakenaikan angka partisipasi sekolah tinggi sebesar 1 persen akan meningkatkan PDB riil sebesar 0,05 persen dalam jangka pendek. Artinya, meski tidak sekuat variabel LELCON dan LINE, namun variabel SET terbukti signifikan mempengaruhi PDB riil baik dalam jangka pendek maupun jangka panjang.

Jika dibandingkan dengan efek jangka panjang, selain variabel konsumsi listrik, nilai koefisien semua variabel lebih rendahdalam jangka pendek. Artinya, pengaruh keempat variabel lainnya selain variabel konsumsi listrik, terbukti lebih kuat dalam jangka panjang daripada jangka pendek. Menariknya, berbeda dalam jangka panjang, variabel konsumsi listrik menjadi signifikan sedangkan variabel angka partisipasi sekolah tinggi menjadi tidak signifikan.Implikasinya, upaya-upaya untuk meningkatkan porsi barang manufaktur dalam komposisi ekspor Indonesia perlu terus didorong guna menjaga keberlanjutan PDB riil. Pada saat yang sama, nilai konsumsi listrik terutama sektor industri pun perlu terus ditingkatkan karena kenaikan tingkat konsumsi listrik akan mengerek kinerja industri ke level yang lebih tinggi. Hal ini tentu akan menciptakan efek berganda yang positif terhadap PDB riil. Selain itu, pengaruh harga komoditas non-energi terhadap PDB masih tetap tinggi baik dalam jangka pendek maupun jangka panjang. Meski begitu, tingkat ketergantungan industri nasional atas komoditas primer perlu mulai dikurangi guna mendukung keberlanjutan dan kualitas pertumbuhan ekonomi di masa mendatang.

\section{Uji Kointegrasi Bounds}

Tabel 4 menunjukkan nilai F-statistik lebih tinggi daripada nilai kritisnya. Karena nilai F-nya > nilai kritisnya, maka hipotesis nol yang menyatakan bahwa tidak terdapat hubungan kointegrasi antar variabel dalam model dapat kita tolak. Karena $\mathrm{H}_{0}$ ditolak, maka dapat disimpulkan bahwa memang terdapat hubungan kointegrasi antara utang rumah tangga dengan tingkat pertumbuhan konsumsi. Begitu pun dengan hasil uji statistik-t. Hasil uji statistik-t menunjukkan bahwa nilai t-statistik lebih kecil daripada nilai kritisnya yang mengindikasikan bahwa terdapat hubungan kointegrasi diantara variabel yang dilibatkan dalam persamaan.

\section{Uji Statistik Tambahan}

Untuk memperkuat hasil uji kointegrasi di atas, maka beberapa uji statistik juga ditambahkan dalam penelitian ini seperti uji 
Tabel 7.Hubungan Kointegrasi Statistik-F dan $\mathrm{t}$

\begin{tabular}{cccccc}
\hline \multirow{2}{*}{ Uji Statistik } & \multirow{2}{*}{ Nilai } & \multirow{2}{*}{ Level Signifikansi } & \multicolumn{2}{c}{ Nilai Kritis Bound } & \multirow{2}{*}{ Hasil } \\
& & & $I(0)$ & $I(1)$ & \\
\hline \multirow{3}{*}{ Statistik-F } & \multirow{2}{*}{5.922} & $1 \%$ & 3.41 & 4.68 & Kointegrasi \\
& & $5 \%$ & 2.62 & 3.79 & Kointegrasi \\
& & $10 \%$ & 2.26 & 3.35 & Kointegrasi \\
Statistik-t & -4.495 & $5 \%$ & -3.43 & -4.79 & Kointegrasi \\
& & $10 \%$ & $-2,86$ & -4.19 & Kointegrasi \\
& & $-2,57$ & -3.86 & Kointegrasi \\
\hline
\end{tabular}

Tabel 8. Beberapa Hasil Uji Statistik

\begin{tabular}{llcl}
\hline \multicolumn{1}{c}{ Uji Statistik } & \multicolumn{1}{c}{ Jenis Uji Statistik } & p-value & \multicolumn{1}{c}{ Hasil } \\
\hline Autokorelasi & White Noise & 0.3240 & Tidak ada otokorelasi \\
Normalitas & Shapiro-Wilk & 0.1343 & Terdistribusi secara normal \\
ARCH & Lagrange Multiplier & 0.7112 & Tidak mengandung efek ARCH \\
\hline
\end{tabular}

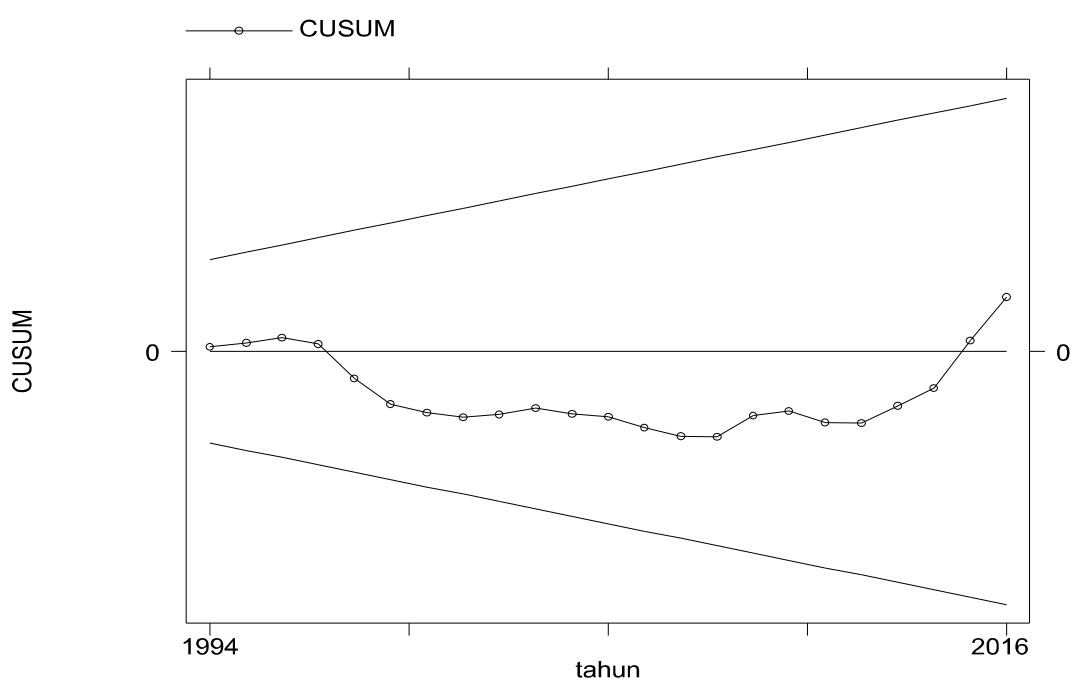

\section{Grafik 1. Uji CUSUM}

autokorelasi dengan menggunakan uji White Noise, normalitas dengan menggunakan uji Shapiro-Walk, dan autoregressive conditional heteroscedasticity (ARCH) dengan menggunakan uji Lagrange Multiplier (LM). Hasilnya ditunjukkan pada tabel 8 di bawah ini. Tabel 8 menunjukkan bahwa model yang digunakan penelitian ini telah lulus tes autokorelasi, normalitas, dan ARCH. Artinya, nilai residual dalam model tersebut tidak mengandung serial korelasi, terdistribusi secara normal, dan tidak mengandung efek $\mathrm{ARCH}$.

Selain uji statistik di atas, penelitian ini juga melibatkan uji cumulative sum of the reisiduals (CUSUM). Tes ini ditujukan untuk menghitungnilai recursive residualdalam model. Jika nilai koefisien estimasi tidak berada diantaradua standard error, maka koefisien tersebut dikatakan tidak stabil. Hasil tes cusum menunjukkan bahwa residual tidak terakumulasi sepanjang waktu (lihat grafik 1). Dengan demikian, dapat disimpulkan bahwa model ekonometrika yang digunakan dalam penelitian ini tergolong cukup baik.

\section{KESIMPULAN}

Tujuan dari penelitian ini adalah untuk melihat pengaruh listrik dan industrialisasi terhadap pertumbuhan ekonomi. Hasil analisis dengan menggunakan model ARDL menunjukkan bahwa pengaruh listrik dan angka partisipasi sekolah tinggi terhadap pertumbuhan ekonomi terbukti positif namun 
dampaknya berbeda dalam jangka pendek dan jangka panjang. Dalam jangka panjang, pengaruh konsumsi listrik tidak begitu signifikan. Namun, dalam jangka pendek, konsumsi listrik justru menjadi penyumbang terbesar terhadap pertumbuhan ekonomi. Berbeda dengan variabel konsumsi listrik, angka partisipasi sekolah tinggi signifikan dalam jangka panjang namun dalam jangka pendek justru tidak signifikan. Adapun porsi barang manufaktur yang diekspor positif dan signifikan baik dalam jangka panjang maupun jangka pendek. Menariknya, kelima variabel yang dilibatkan terkecuali konsumsi listrik, memiliki nilai koefisien yang lebih tinggi pada jangka panjang dibandingkan jangka pendek. Artinya, keempat variabel tersebut memiliki pengaruh yang lebih tinggi dalam jangka panjang daripada jangka pendek. Menariknya lagi, dari kelima variabel yang dilibatkan, konsumsi listrik justru menjadi variabel yang memiliki daya dorong yang kuat untuk mendongkrak kinerja pertumbuhan ekonomi dalam jangka pendek.

\section{IMPLIKASI KEBIJAKAN}

Analisis diatas mengonfirmasi bahwa konsumsi listrik memainkan peran yang cukup penting dalam mendorong pertumbuhan ekonomi dalam jangka pendek.Dengan demikian, guna menjaga stabilitas pertumbuhan ekonomi dalam jangka pendek, makaupaya-upaya untuk meningkatkan konsumsi listrik perlu terus didorong. Sementara untuk mendorong pertumbuhan ekonomi dalam jangka panjang, pemerintah perlu meningkatkan porsi barang manufaktur dalam struktur ekspor nasional dan angka partisipasi sekolah tinggi. Dengan angka partisipasi sekolah tinggi yang meningkat, maka migrasi pekerja ke sektor industri akan menjadi lebih tinggi daripada ke sektor pertanian. Hal itu akan menggerakkan daya saing industri dan juga tingkat pendapatan karena sektor industri manufaktur menawarkan upah yang lebih tinggi dibandingkan sektor pertanian. Dengan upah yang lebih tinggi, akan mengerek tingkat konsumsi termasuk konsumsi listrik ke level yang lebih tinggi. Pada akhirnya, laju pertumbuhan ekonomi bisa naik ke level yang lebih tinggi.

\section{DAFTAR PUSTAKA}

Adam, L. (2016). Dinamika Sektor Kelistrikandi Indonesia: Kebutuhan dan Performa Penyediaan, Jurnal Ekonomi dan Pembangunan, Vol.4 No.1, hal.2941.

Acaravci, A., \& Ozturk, I. Eletricity Consumption-Growth Nexus: Evidence from Panel Data for Transition Countries, Energy Economics Vol.32, hal.604-608.

Bank Indonesia. (2015). Profil Bisnis Usaha Mikro, Kecil, dan Menengah (UMKM). Kerjasama Lembaga Pengembangan Perbankan Indonesia (LPPI) dengan Bank Indonesia.

Badan Pusat Statistik. (2017). Statistik Indonesia 2017. Diunduh dari https:// www.bps.go.id/publication/2017/07/26/ b598fa587f5112432533a656/statistikindonesia-2017.html

Buhaerah, P. (2018). Membedah Daya Saing Industri. Harian Bisnis Indonesia, edisi 14 Maret 2018.

Jesus, F. (2012a). Tackling the MiddleIncome Trap. What is it, Who is in it, and Why? Part 1, ADB Economics Working Paper Series No.306, Manila: Asian Development Bank.

Jesus, F. (2012b). Tackling the MiddleIncome Trap. What is it, Who is in it, and Why? Part 2, ADB Economics Working Paper Series No.307, Manila: Asian Development Bank.

Johansen, S. (1991). Estimation and Hypothesis Testing of Cointegration Vectors in Gaussian Vector Autoregressive Models, Econometrica, Vol. 59 No.6, hal. 15511580.

.Odhiambo, N.M. (2010). FinanceInvestment-Growth Nexus in South Africa: An ARDL-Bounds Testing Procedure, Economic Change and Restructuring, Vol.43 No.3, hal. 205-219.

Paus, E. (2017). Escaping the Middle-Income Trap: Innovate or Perish, ADBI Working Paper Series No.685, Tokyo: Asian Development Bank Institute.

Pesaran, M. H., \& Shin, Y. (1998). An Autoregressive Distributed-Lag Modelling Approach to Cointegration Analysis. In Econometrics and Economic Theory in the 20th Century. The Ragnar Frisch Centennial Symposium, ed. S. Strom, chap. 11, hal. 371-413. 
Cambridge: Cambridge University Press.

Pesaran, M. H., Shin, Y., \& Smith, R. (2001). Bounds Testing Approaches to the Analysis of Level Relationships, Journal of Applied Econometrics, Vol. 16, hal. 289-326.

Perusahaan Listrik Negara. (2017). Statistik $P L N$ 2016. Sekretariat Perusahaan PT. PLN (Persero).

Rodrik, D. (2017). Pertumbuhan tanpa Industrialisasi. Diakses pada 1 Desember 2017 di https://www.project-syndicate. org/commentary/poor-economiesgrowing-without-industrializing-bydani-rodrik-2017-10/indonesian

Sambodo, M. T., \& Oyama, T. (2011). Investigating economic growth and energy consumption in Indonesia: Time Series Analysis 1971 to 2007. Review of Indonesian Economics and Bussiness Studies, Vol.2, No.2
Squally, J. (2007). Electricity Consumption and Economic Growth, Bounds and Causality Analyses of OPEC Members, Energy Economics Vol.29, hal.11921205.

World Bank. (2017). World Development Indicators. Diunduh dari https://data. worldbank.org/data-catalog/worlddevelopment-indicators.

Yoo, S. H., \& Kim, Y. (2006). Electricity Generation and Economic Growth in Indonesia, Energy Vol.31, hal. 28902899.

Yoo, S. H. (2005). Electricity Consumption and Economic Growth: Evidence from Korea, Energy Policy Vol.33, hal.16271632.

Yoo, S. H., \& Lee, J. S. (2010). Electricity Consumption and Economic Growth: A Cross-Country Analysis, Energy Policy Vol.38, hal.622-625. 